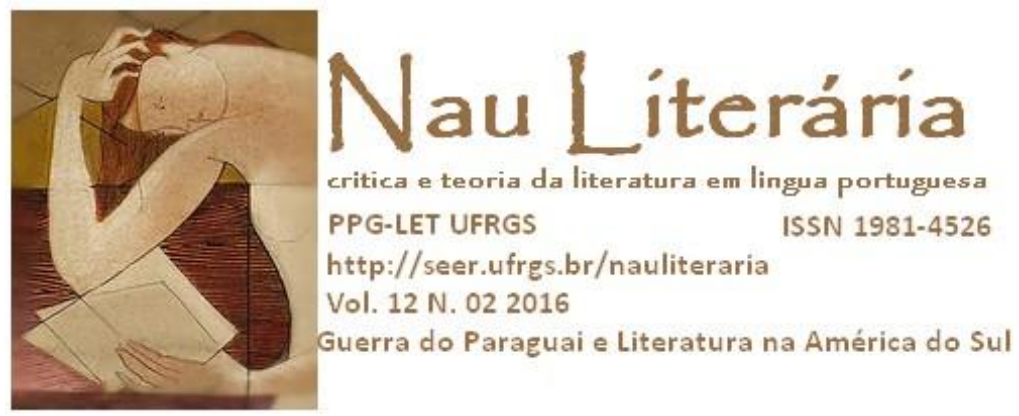

\title{
Apresentação: A Guerra do Paraguai na Literatura
}

Gerson Roberto Neumann

Rita Lenira de Freitas Bittencourt

A história da humanidade, integrada em sociedade(s), está intimamente associada a conflitos, confrontos e guerras. Para muitas sociedades, existia, e cremos que ainda exista, a necessidade de práticas bélicas. Desde os tempos mais remotos, as guerras fazem parte, portanto, da nossa trajetória.

A consolidação das nações e de seus grandes exércitos é marcada por afirmações de fronteiras e de identidades. Muitas sucumbiram em virtude de guerras e outras surgiram e se afirmaram por causa delas. A história do Brasil também é marcada por uma guerra de grandes proporções no contexto regional, na América do Sul, no século XIX, o século da formação de estados nacionais e, por consequência, de muitas guerras. Estamos falando da Guerra do Paraguai. O mês de dezembro de 1864 marcou o início da maior guerra travada na América do Sul. A história relata a guerra da Tríplice Aliança formada por Argentina, Brasil e Uruguai contra o Paraguai. Questões políticas, econômicas e de fronteira - transposições, invasões, desrespeitos e provocações figuram como prováveis causas desta guerra que é tida como a mais terrível, em solo sul-americano, pelo número de mortos, principalmente do lado paraguaio.

Os conflitos de fronteira e a temática da guerra também são constantes em textos ficcionais. A Guerra do Paraguai é tema pouco recorrente na literatura brasileira, mas textos existem e eles foram pouco estudados. O presente número temático da Revista Nau Literária é consequência de uma jornada que se propunha a iniciar uma discussão em torno do tema guerra e dos conflitos de fronteira pensados em seus efeitos na 
literatura brasileira e na teoria literária. No evento, discutiram-se as conexões da Guerra do Paraguai com a produção ficcional, embora, em plano geral, tenha sido impossível esquecermos de outras guerras e conflitos, desde a Antiguidade.

Os textos apresentados a seguir trazem reflexões em torno dessa temática, desenvolvendo-a em diferentes direções. Abrindo a edição, temos uma abordagem da guerra na Antiguidade: "Visualizando a guerra no mundo antigo: o caso de Homero e da Lírica Grega", na qual Rafael Brunhara analisa as primeiras representações literárias da guerra na literatura ocidental. O autor concentra-se na Ilíada de Homero e em exemplos da lírica grega arcaica, oferecendo um panorama do sistema de valores que as enformam e enfatizando o forte caráter imagético de suas descrições, que intentam delinear uma visão idealizada da guerra.

Passando direto ao cenário da Guerra da tríplice aliança, em "Roa Bastos, compilador da história paraguaia", Karina de Castilhos Lucena esboça um breve panorama da história paraguaia, a partir da produção do escritor Augusto Roa Bastos, que a registrou em sua ficção, em especial nos romances Hijo de hombre (1960) e Yo el Supremo (1974). Temos em Roa Bastos um grande exemplo de literatura em diálogo com os outros saberes, preocupada com as marcas do passado e com o resgate dos fatos históricos em tempos atuais.

Já Carlos Rizzon, apoiado na historicização da ficção - conceito do pensador francês Paul Ricoeur -, faz uma análise do conto Don Sejanes, de Aldyr Garcia Schlee, e do romance No robarás las botas de los muertos, de Mario Delgado Aparaín, no artigo "Conflitos fronteiriços no preâmbulo da Guerra do Paraguai", enfatizando como as abordagens literárias potencializam os questionamentos e desmitificam as glórias que recobrem o imaginário popular, uma vez que é possível estabelecer relações entre os enfrentamentos ocorridos em Paysandú e em Jaguarão e provocar uma desestabilização das heroicidades que sustentam o orgulho dos habitantes dessas cidades, de ambos os lados da fronteira.

No texto "Narratives that travel acrosss pace and time: the intertextuality of Eliza Lynch", Anelise Corseuil traz à discussão uma abordagem cinematográfica sobre o tema da Guerra do Paraguai e, mais especificamente, sobre uma figura feminina muito marcante no conflito. Trata-se de Eliza Alicia Lynch, personagem do filme Eliza Lynch: a Rainha do Paraguay (2013), de Alan Gilsenan. A abordagem teórica se volta para a 
leitura de filmes contemporâneos sobre viagem, que problematizam o conceito das fronteiras nacionais, as inter-relações entre o público e o privado e as formas narrativas utilizadas para representar os encontros inter-hemisféricos entre pessoas de diferentes raças e etnias.

Partindo de condições externas à Guerra do Paraguai, mas em estreito diálogo com ela, Ian Alexander apresenta o conto The Battle of Acosta Nu [A batalha de Acosta $\mathrm{Nu}$ ], do australiano Gerald Murnane, do livro Landscape with Landscape [Paisagem com paisagem], de 1985. No artigo, "Gerald Murnane e a escala da literatura", explicase o fundamento histórico do conto - o contexto australiano na década de 1890 e a fundação da colônia Nova Austrália no interior do Paraguai. Analisa-se ainda a Batalha de Acosta Nu e aborda-se a questão da escala na literatura, especulando o quanto a obra de Murnane, com seu foco em Melbourne, pode ser compreendida no Brasil.

Na Guerra do Paraguai, lutaram muitos imigrantes e filhos de imigrantes alemães e muitas foram as críticas aos líderes políticos brasileiros por forçarem os imigrantes a participarem da guerra. Muitos morreram na guerra, poucos sobreviveram. Alguns destes registraram sua participação nas batalhas em forma de texto, publicados na imprensa em língua alemã em terras brasileiras. Em "A Guerra do Paraguai na imprensa e na literatura de língua alemã publicada no Brasil”, Gerson Roberto Neumann traz um poema épico redigido por um imigrante que lutou na Guerra do Paraguai.

Conforme Rita Lenira de Freitas Bittencourt, no artigo "Guerra em deriva: Poéticas de fronteira”, a Guerra do Paraguai, Guerra da Tríplice Aliança, ou Grande Guerra do Brasil, reverbera, no presente, suas poéticas: são derivas multilíngues e oscilantes, que carregam nos usos escritos e orais os rastros e formas dos contatos e conflitos. Especialmente em espaços fronteiriços, as formas linguísticas recompõem-se e reinventam-se nas dicções em convívio e nas produções literárias, nas quais o espanhol, o guarani e o português se reconhecem e se estranham.

Fechando o conjunto a respeito da Guerra do Paraguai na literatura, Alai Garcia Diniz, em "Nambrena, falcatrua e Curuzu na Guerra Guasu da América do Sul", trabalha os conceitos de arquivo e repertório. Traz à discussão o "diário de Taunay ou carta de um militar no Forte Curuzu de 1866" e discute o repertório a partir da proposta de Diana Taylor, 2013. Além disso, expande a leitura para uma tela de Cándido Lopez e 
para o documentário Guataha, de 2015. Segundo a autora, "entre o passado bélico e as batalhas entre aldeia indígena e hidroelétrica nada mais há que um estopim para a leitura da violência na contemporaneidade."

Completam o número da revista duas resenhas de obras muito relevantes sobre o tema desta edição: Luciane da Silva Alves aborda o livro Adeus, Chamigo Brasileiro Uma história da Guerra do Paraguai, de André Toral, publicado em 1999, que inicialmente integrou a tese de doutorado do autor e foi republicado em 2008 pela Cia das Letras. O livro narra a Guerra do Paraguai em ilustrações e histórias em quadrinhos. A narrativa de André Toral é baseia-se em pesquisas históricas e em iconografias da época a que se refere o texto; Carla Luciane Klôs Schöninger ocupa-se do livro Guerra do Brasil: contos da Guerra do Paraguai, de Sylvio Back, 2010. O livro esboça, de modo irônico, fatos e situações ocorridas durante essa guerra - entre dezembro de 1864 e março de 1870, que acabou por destruir a economia e a população paraguaia. Em sua escrita, Sylvio Back utiliza-se da figura de líderes políticos e militares.

A produção panorâmica aqui apresentada confirma e, de algum modo, contradiz a afirmação inicial desta Apresentação, de que a guerra contra o Paraguai teria sido pouco explorada no plano ficcional. Percebemos que há muitos textos ainda por descobrir, no esforço transnacional de desvendar um passado comum. No sentido historiográfico, vasculhar os fatos da história retomados pela literatura torna-se uma tarefa necessária e importante. 